\title{
A.IR MAII
}

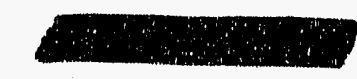

HAN -74331

TO: Dlrector, Division of Production

DE92 018694

USAEC, Washington, D. C.

FROM: J. E. Travis, Manager, Hanford Operations

Office, USAEC, Richland, Washington

SUBJECT: MONTHLY STATUS AND PROGRESS REPORT

S"IIBOI: $\quad$ B:KEI

Enclosed hererith is Part I report for the month of "Official Use Only" portion, Part II, is formaried is a separate report.

Cuminication Cencetied (Chunes to

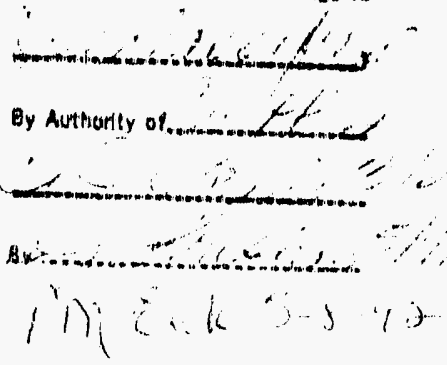

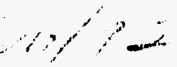

Enclosure:

Cy. \# Monthly Status and Progress Report, Part I Document if Fanford $7 \leq \angle B A$

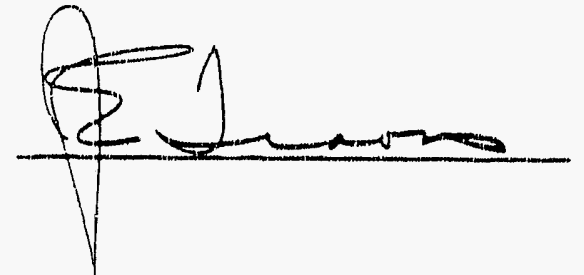

$0=0-1=30=0+1:$

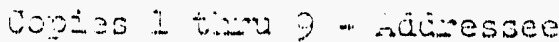

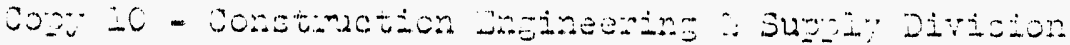

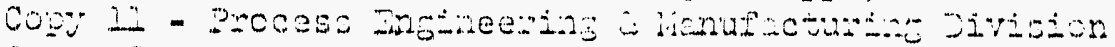

Con ze - Secunitu zivision

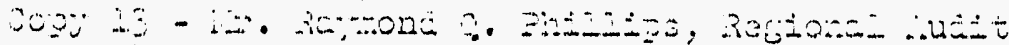

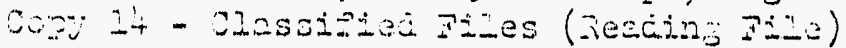

$\rightarrow \cos 15-3 u c g e t-2 i v i s i o n$
When separated from enclosure, handle this document as UNCLASSIFIED.

AIR MAII

DISTRISUTION AESTRIOTEO TO OYR WOATRICTED TO U.S. ONLY 

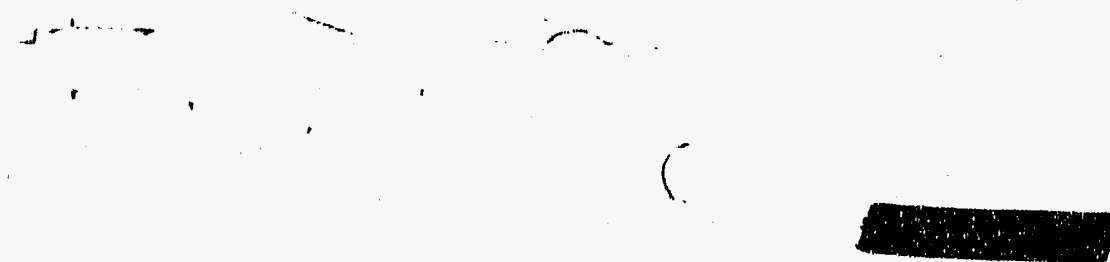

DOCUMENT NO. HAN-74331

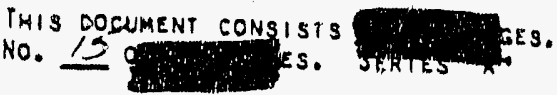

U. S. ATOMIC ENERGY COMAISSION

HANFORD OPERATIONS OFFICE

\section{MONTHLY STATUS ANO PROGRESS REPORY}

QECEMBER 1959

PART I

\section{DISCLAIMER}

This report was prepared as an account of work sponsored by an agency of the United States Goverrment. Neither the Urrited States Government nor any agency thereof, nor any of their employees, makes any warranty, express or implied, or assumes any legal liability or responsibility for the accuracy, completeness, or usefulness of any information, apparatus, product, or process disclosed, or represents that its use would not infringe privately owned rights. Reference herein 10 any specific commercial product, process, or service by trade name, trademark. manufacturer, or otherwise does not necessarily constitute or inply its endorsement, recommendation, or favoring by the United States Government or any agency thereof. The views and opinions of authors expressed herein do not necessarily state or reffect those of the United States Government or any agency thereof.

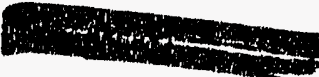




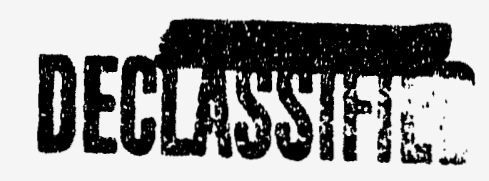

DOCUMENY NO. HAN-74331

MON TMLY STATUS AND PROGRESS REPORT

HANFORD OPERATIONS OFFICE

DECEMBER 1959

PART 1

C $Q N I E N I S$

PAGE NOO

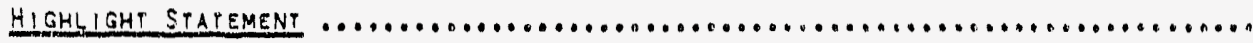

PLANT OPERATIONS

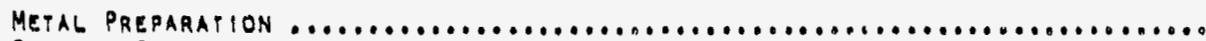

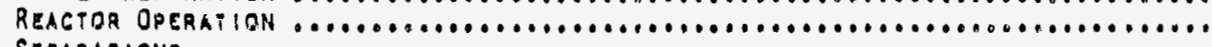

SEPARATIONS ...................................................

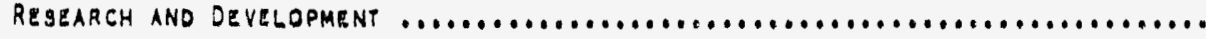

4.6

$6 \div 7$

PLANT ACQUISITION AND CONSTRUCYION

PROJEGT AND DESIGN STUDIES .......................................

Plant Congtruction ...............................................

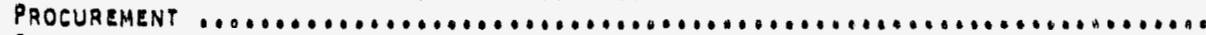

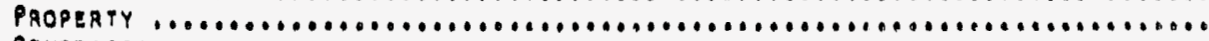

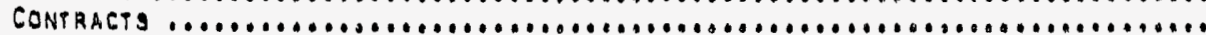

NPR INPORMATION CENTER 00000000000000000000000000000000000000000000000000000

9

$10 \cdot 11$

19

11

12 


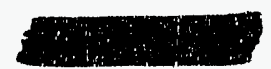

DOCUMENT NO. HAN-74331

HIGHLIGHT STATEMENT - DECEMBER 1959

\section{OPERATIONS}

CANNED PUEL ELEMENT PRODUCTION TOTALED 632 TOHS, 97.76 OP FORECAST. THE TOTAL CONSISTED OF 54 TONS OF SOLID AND 497 TONS OP ISE NORMAL.URANIUM AND 81 TONS OP ISE 94-METAL. YIELDS HERE 39.8\% FOR SOLIO AND $85.8 \%$ FOR ISE NORMAL-ISRANIUM AND 83.0\% FOR 94-METAL PIECES.

IN-REACTOR PROQUCTION HAS 108. G\% OF POREGAST. THE OVER-ALL AVERAGE TIME-OPERATED ETPICIENCY WAS 82.2\% AS COMPARED WIYH THE 827 PORECAST. NEW MAXIMUM POWER LEVEL RECORDS WERE ESTABLISHED AT $C, D, F, K, K E$, AND KW REACTORS. INDIVIDUAL. REACTOR PRODUCTION RECORDS WERE ESTABLISHED AT D AND KW. DURING PHE MONTH, THERE NERE 10 NORMAL-URANIUM FUEL ELEMENT PAIIUREs, THESE INCLUDED 9 I\&E ELEMENTS AND ONE SObID ELEMENT. THERE WERE ALSO TNO PRODUCTION TEST, RUN-TORUPTURE 1.47-METAL PALLURES AT B PEACTOR.

TOTAL SEPARATIONS PLANT PLUTONIUM PRODUCTION WAS 124.5\% OP PORECAST HITH 78.5\% OF THE TOTAL PRODUCED BY PUREX AND 21.56 GY REDOX. A TOTAL OP 1,090 GRAMS OF NEPTUNIUM WAS RECOVERED YROM PUREX AND 70 GRAMS hAS RECOVERED FROM the REDOX PLANT.

PRODUCTION OR NOAMAL UO 3 TOTALED 55.3 TONS, 110.6\% OP FORECAST. ENRICHED UO PRODUCTION TOTALED 48.2 TONS, 102.3\% OF PORECAST. ALL SHIPPING SCHEDULES WERE MET.

PLANT ACQUISITION AND CONSTRUCTION

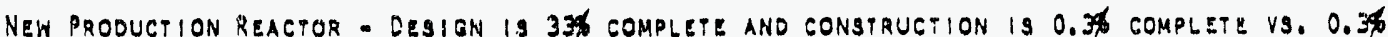
SCHEOULED. DURING THE MONTH WORK WAS STARTED ON THE SUPDORTING TELEPKONE PACILITIES, THE RIVER PUMP hOUgE, aND T-G gUILDINOS aNo PACILITIES. (SEE PART 1, PAGE 11.)

CONPINEMENY - DESION IS 68\% COMPLETE, AND CANSTRUCTION IS $20 \%$ COMPLETE VS, $20 \%$ SCHEDULED. (SEE PART, PAGES 9 AND 10.)

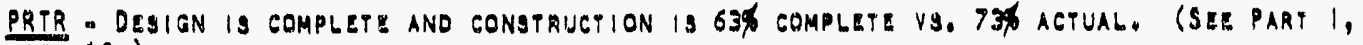
PAGE 10.$)$

PPPP - DESION IS 95\% COMPLETE ANO CONGTRUCTION 19 8\% COMPLETE VS. 95\% SCHEDULED. (SEE PRRT I, PAQE 9.j

GOMMUNITY

PROPEREY DLIROSAL - A YOTAL OP 5,107 OP 5,360 SALE PROPERTIES HAVE BEEN SOLD ANO AN ADOI. PIONAL J2 GOOO PAITH DEPOSITS PLAGED. (SEE PART II, PAGE 4.)

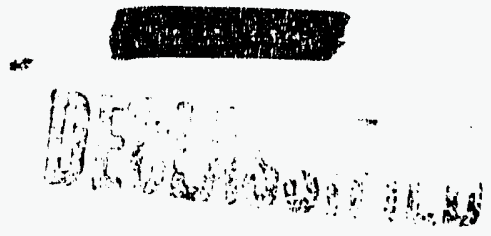





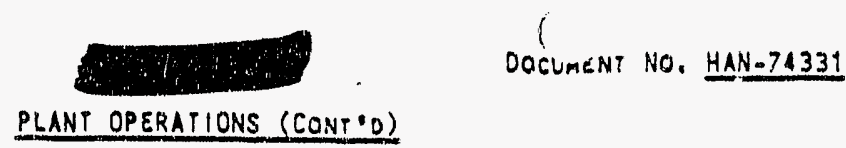

REACTOR OPERATION (CONT 'D)

FOLLOWING IS A SUMMARY OF DECEMBER REACTOR DUTAGES:

\begin{tabular}{ll} 
OATE & \multicolumn{1}{c}{$\begin{array}{c}\text { DATE } \\
\text { UOWN }\end{array}$} \\
\hline 3 REACTOR: \\
\hline $11-27$ & $12-1$ \\
$12-1$ & $12-1$ \\
$12-1$ & $12-1$ \\
$12-14$ & $12-18$ \\
$12-18$ & $12-18$ \\
$12-23$ & $12-23$ \\
$12-23$ & $12-24$ \\
$12-30$ & STILL \\
& OOWN
\end{tabular}

OUTAGE

HOURS

91.3

1.6

0.3

102.5

0.3

0.3

37.4

\section{REACYOR:}

$12-9 \quad 12=12$

68.2

$12.13 \quad 12-13$

$12-14 \quad 12-16$

5.0

33.0

$12-18 \quad 12.18$

$12.27 \quad 12.30$

0.3

58.1

$12-30 \quad 12-30$

$12-30 \quad 12.30$

0.7
5.7

Q REACTOR:

$11-29 \quad 12 \times ?$

$12-23 \quad 12.25$

66.2

43.4

\section{DR REAGIOR:}

$12.7 \quad 92.1$

98.0

$12-17 \quad 12.19$

50.1

$12.26 \quad 12.27 \quad 36.0$

\section{preacior:}

$\begin{array}{lll}12.8 & 12.12 & 101.5 \\ 12-25 & 12.27 & 42.2\end{array}$

\section{H REACTOR:}

$\begin{array}{rrr}12-11 & 12-12 & 49.8 \\ 12-28 & 12-28 & 0.2 \\ 12-28 & 12-30 & 39.7\end{array}$

$12 \cdot 30 \quad 12 \cdot 30$

\section{KE REACTOH:}

$\begin{array}{llr}12-7 & 12-10 & 65.4 \\ 12-10 & 12-10 & 1.1 \\ 12-10 & 12-10 & 3.0 \\ 12-23 & 12-24 & 36.3 \\ 12-27 & 12-29 & 19.6\end{array}$

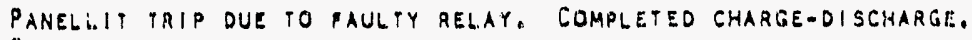
PANELLIY TRIP.

PANEL-:IT TRIP CAUSED gy OSCILLATING GAUge.

SCHEDULED CHARGE-DISCHARGE, LEAK IESTING, AND TUBE PEPLACEMENY. PANELLIT TRIP.

PANELLiT TR:P CAUSED GY PLUGGED CONE SCREEN.

PANELLIT IRIP CAUSED BY A STUCK ISE, 1.4T-METAL, PRODUCTION EST PIJEL ELEMENT PAILURE IN TUBE 1770.

REMOVAL OP A STUCK ISE, 1.4T.METAL, PRDOUCTION TEST PUEL ELEMENT PAILURE PRCM TUQE 1764 .

REMOYAL OP AN ISE NORMAL - LRANIUM PUEL ELEMENT FAILURE FROM IUAE 2484 AND CHARQL-DISCHARQE.

POISON DISCHAROE.

INVESTIGATION OP UNCONPIAMEO FUEL ELEMENT PAILUAE SUSPECT. GOMPLETEO CKARQE-DISCHARGE.

PANELLIT TRIP.

REMOVAL OF A gTUCX ISE NORMALUURANIUM PUEL LLEMENT RAILURE PROM TUBE 2362. COMPLETLO GHARQE DISGHARGE AND TUQE REPLACEMENT. panellit paip gaused or a rlugiuating aAube.

POISON DISCMARGL.

COMPLETEU TUBE RLPLACEMENT, POLLOWINO A PANCLLIT TRIP. PANELLIT TRIP GAUSEO OY A NORMAG-URANIUH PUEL ELEMENT MILURE IN PUBE 2661. COMPLETED GHARQE-DISCHARGE.

WATER LEAK GAUSKD OY ISE NORMALOURANIUM FUEL KLEMENT PAILURE IN FUBR 3975, ANO CHARQR-DISCHAROE.

PANELLIT PRIP. MAINTENANCE ANO POOUCTION TEST WORK WERE PERPORMED. LEAK TESTINO AND GMAROL-DISCHARQR.

REMOVAL OF AN ISE NORMAL-URANIUM PUEL ELEMENT PAILURE PROM TUEE 3469. COMPLETED GHARQE OISCHARQE AND MAINTENANCE WORK. REMOYAL OF AN ISE NORMAL URANIUM PUEL RLEMENT PAILUAE YROM TUBE 3467 AND CHARGE DISCHARQE.

TRIP DUE TO A POWER SURGE ON NO. 3 LINE AT MIOWAY. COMPLETED MAINTEHANCE WORK DURING PERIOD OF INSUFPICIENT REACTIVITY.

PANELLIT TRIP ON TUEE 3668 .

MANUAL TRIP OUE TO INDICATIONS OP A WATER LEAX. REMOVAL OF A STUCX ISE NORMal. URANIUM PUEL ELEMENT PAILURE PROM TUBE 3660, COMPLETED CHARGE-DISCHARGE AND TUBE REPLACEMENT.

Paneliti trip gaused ay pluctuating gauge.

SCHEDULED CHARGE DI BCHARGE.

RESISTANCE TEMPERATURE DETECTOR REPAIR.

POISON DISCHARGE.

REMOVAL OF A STUCK ISE NORMALUURANIUM PUEL ELEMENT PAILURE PROP TUBE 2350 AND GHARGE-DISCHARGE.

REMOVAL OF A MTUCK SOLID, NORMAL -URANIUM FUEL ELEMENT FAILURE FROM TUQE SI 78 AND GHARGEODISCHARGE. 


\section{DATE DATE OUTAGE}

DOWN UP HOURS

KW REACTOR:

$\begin{array}{llr}11-29 & 12-1 & 61.3 \\ 12-2 & 12-2 & 4.2 \\ 12-19 & 12-21 & 51.7 \\ 12-21 & 12-21 & 4.2\end{array}$

REMARKS

FUEL ELEMENT FAILURES - FOLLOWING IS A SUMMARY OP DECEMBER FUEL ELEMENT FAILUPES:

SCMEDULED CHARGE-DISCHARGE AND MAINTENANCE.

SOISON DISCHARGE.

REMOVAL OF A STUEK I\&E NORIMAL-URANIUM FUEL ELEMENT FAILURE FROM TUBE 2649 AND CHARGE-DISCHARGE.

POISON DISCHARGE.

TABULAT!ON OF RUPTURED URANIUM SLUGS

\begin{tabular}{|c|c|c|c|c|c|}
\hline TUBE NO. & $\begin{array}{c}\text { DATE } \\
\text { RUPTURED }\end{array}$ & $\begin{array}{l}\text { TUBE } \\
\text { Powerail }\end{array}$ & $\begin{array}{l}\text { TONCENTRATION } \\
(M W O / T)\end{array}$ & 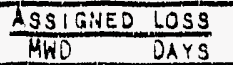 & TYOE EAILURE \\
\hline
\end{tabular}

(NORMAL)

\begin{tabular}{|c|c|c|c|c|c|c|c|}
\hline $\begin{array}{l}3975-O R \\
3469-F \\
2484-C \\
2549-K W \\
3350-K E \\
2661.0 \\
3467-F \\
2362-C \\
5578-K E \\
3668-H\end{array}$ & $\begin{array}{l}12-7 \\
12-8 \\
12-9 \\
12-19 \\
12-23 \\
12-23 \\
12-25 \\
12-27 \\
12-27 \\
12-28\end{array}$ & $\begin{array}{l}1026 \\
1109 \\
1224 \\
1461 \\
1344 \\
1035 \\
1187 \\
1176 \\
976 \\
1028\end{array}$ & $\begin{array}{l}744 \\
531 \\
427 \\
595 \\
413 \\
815 \\
380 \\
570 \\
525 \\
660\end{array}$ & $\begin{array}{l}1370 \\
1316 \\
1272 \\
5735 \\
1619 \\
2284 \\
77 \% \\
3539 \\
2847 \\
1383\end{array}$ & $\begin{array}{l}0.83 \\
0.82 \\
0.72 \\
1.08 \\
0.49 \\
9.43 \\
0.48 \\
2.01 \\
0.86 \\
0.85\end{array}$ & $\begin{array}{l}18 E \\
18 E \\
18 E \\
18 E \\
18 E \\
18 E \\
18 E \\
18 E \\
S O L 10 \\
18 E\end{array}$ & $\begin{array}{l}\text { SIDE OTHER. } \\
\text { SIDE OTHER. } \\
\text { SIDE HOT SPOT. } \\
\text { HOT SPOT. } \\
\text { UNDETERMINED. } \\
\text { UNDETERMINED. } \\
\text { UNDETERMINED. } \\
\text { HOT SPOT. } \\
\text { UNOETERMINED. } \\
\text { SIDE OTHER. }\end{array}$ \\
\hline \multicolumn{8}{|c|}{$(1.47$ KEYAL $)$} \\
\hline $\begin{array}{l}1770-8 \\
1764-8\end{array}$ & $\begin{array}{l}12-23 \\
12-30\end{array}$ & $\begin{array}{l}1075 \\
1025\end{array}$ & $\begin{array}{l}286 \\
238\end{array}$ & $\begin{array}{l}2342 \\
1914\end{array}$ & $\begin{array}{l}1.67 \\
1.36\end{array}$ & $\begin{array}{l}P Y \text { ISE } \\
\text { PY ISE }\end{array}$ & $\begin{array}{l}\text { HOT gPOT. } \\
\text { SIDE OTHER. }\end{array}$ \\
\hline
\end{tabular}

PUBE REPLACEMENT - THERE WERE 62 TUBES INGTALLED DURING YHE MONTH OF DEGEMBER: 24 AT F, 20 AT B, TAT $6,5 A T D R, 3$ AT KE, 2 AT H, AND I AT KW REACTOR.

TWO OP THE TUBES INSTALLED AT $C$ WERE RIBLES3 ZIRCONIUM TUBZS, WHICH WERE INGTALLED TO PILOT INGTALLATION PROBLEMS, MYDRAULIC CHARAETERIBTIGS, AND CONYERSION RAT IOS PRIOR TO THE 100-TUBE INGTALBATION. DURINO THE MONTH, 6 PROCESS PUBE LEAKS WERE CORREGTED: 2 AT B, 2 AT DR, 1 AT F, AND 1 AT H REACTOR.

SHIELP PROTECTION - Frinat POISONINO FOR F REAGTOR SHIELD PROTECTION WAS CHARGED dURINQ THE MONTH. SIX TOP COLUMNS AND FIVE RAR-gIDE COLUMNG WERE CHARGED WITH LITHIUM. TO COMPENGATE POR THE REACTIVITY LOST GY GHARQINO THE LITHIUM, APPROXIMATELY THAEE TIMES AS MANY COLUMNS WERE GHAROED WITH 94 METAL.

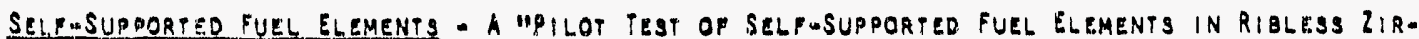
CONIUM PROCESS TUBES" WAS BEGUN AT G REACTOR. THE TWO RIBLESS ZIRCONIUM TUBES INSTALLED DURING THE MONTH WERE GHARGED WITH GELF-gUPPORTED IQE FUEL ELEMENTS. IEMPQRATURE DATA iNDICATED ISSENTIALLY NO UNBALANCE AROUND PHE FUEL ANNULUS, GUT INITIAL DATA INDICATE THAT A SLight REDUCTION IN PUEL O.D. WILL BE DESIRABLE.

THE FIRST COLUMN OP SELF-SUPPORTED PUEL ELEMENTS HAYING THE SUPPORTS ATTACHED BY THE ULTRASONIC WELDING PROCESS WAS CHARGED INTO B REACTOR. NO PROBLEMS WERE ENCOUNTERED.

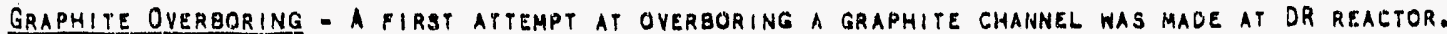
ALL EQUI PMENT UTILIZED IN THE TEST, EXCEPT GOR THE CUTTER ITSELF, OPERATED PROPERLY. THE

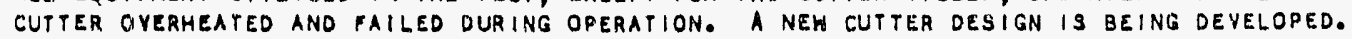

\section{SEPARATIONS:}

TOTAL SILPARATIONS PLANT PLUTONIUM PROOUETION WAS $124.5 \%$ OF FORECAST $2 /$ WITH $78.5 \%$ OF THE TOTAL PRODUCED BY PUAEX ANO $21.5 \%$ BY REDOX.

I/ AT TIME OF RISPTURE.

2f IOSECRET DOCUMENT HAN-73696, JOMNSON/TRAVIS, DATED OCTOBER 23, 1959, SUBJECT 'HAPO PRODUCTION FORECAST." 
PUREX - THE PLANT PROCESSEd 444 TONS OF URANIUM DURING THE mONTH. THE NEPTUNIUM RECOVERY BEGUN IN NOVEMBER WA3 COHPLETED EARLY IN THE MONTH. A TOTAL OF 1,090 GRAMS GF NEPTUNIUM WAS RECOYERED FROM AN ESTIMATED BEGINNING INVENTORY OF 1,380 GRAMS. NEPTUNIUM BEARING SOLVENT WAS REPROCESSED DURING SUBSEQUENT PLANT. OPERATION.

PLUTONIUM PROCESSING WAS RESUMEO DECEMGER 6 AND CONTINUED UNTIL DECEMBER 9 WHEN OPERATIONS WERE SUSPENDED FOR JUMPER REPLACEMENT. THE FINAL PLUTONIUM AND URANIUM CYLLES WERE FLUSHED DURING THE OUTAGE IN AN EPFORT TO IMPROVE DECONTAMINATION OP THE FINAL PRODUCT. OPERATIONS WERE RESUMED DECEMBER 13 AND WERE GONTINUOUS THROUGHOUT THE REMAINDER OF THE MONTH.

TWO SEVERE PROCESS UPSETS OCCURRED DURING THE REMAINDER OF THE MONTH. ON DECEMBER 16, INCREASED PROCESSING RATES CAUSED THE IC COLUMN TO FLOOD, AND APPROXIMATLLY 3, OOO GALLONS OF ORGANIC MATERIAL CONTAINING HIGH GAMMA ACTIVITY WAS RELEASED TO THE FINAL URANIUM CYCLE EQUIPMENT. THE EINAL URANIUM CYCLE WAS SHUT DOWN FOR 16 HOURS TO TRANSFER THIS ORGANIC MATERIAL TO A STORAGE TANK.

THE SECONO PROCESS UPSET OCCURRED ON DECEMESB 2 : WHEN THE PROCESSING OF REWORX MATER:AL CAUSED AN INCREASE IN GAMMA ACTIVITY THROUGHOUT THE PLANT.

THE PLUTONIUM ANION EXCHANGE EQU:PMENT IVAS SHUT DOWN FOR APPROXIMATELY 24 HOURS ON DECEMEER 22 FOR REPAIR OF A VALVE PAILURE CAUSED BY AESIN PLUGGING OF THE FEED LINE.

ALi OP THE URANIUM PRODUCED DURING THE MONTH REQUIRED REWORK OR SILICA-GEL TREATMENT. FIFTY FIVE PERCENT OF THE PLUTONIUM EXCEEDED SPECIFICATIONS AND REQUIRED REWORK OR BLENDING.

WASTE SOSSES TOTALED 0.4\% OF THE PLUTONIUM THROUGHOUT AND $0.21 \%$ OF THE URANIUM THROUGHPUT. HIGH WASTE LOSSES RESULTED FROM THE DISCARD OF DECONTAMINATION PLUSHES OR THE SOLVENT EXTRACTION EQUIPMENT, ABNORMALLY HIGH CENTRIYUGE CLEAN-OUT LOSSES AND PROCESS ADJUSTMENTS TO IMPROVE DECONTAMINATION,

IODINE EMISSIONS AVERAGED 0.75 CURIES PER DAY.

REDOX - THE PLANT PROCESSED 125 TONS OF NORMAL. URANIUM AND 9.8 TONS OF 9A METAL.

OPERATIONG WERE SUSPENDED NOVEMBER 30 POR THE FIRST NEPTUNIUM RECOVERY OUTAGE ATTEMPTED AT THE REDOX PLANT. A TOTAL OP 7 I G GRAMS OF NEPTUNIUM WAS SEPARATED. THE PLANT REGUMED OPERATION DECEMgER 7 ON NORMAL-URANIUM FEED MATER!AL TO ASSIST PUREX IN MEETING QUARTERLY PRODUGTION PORECASTS.

OPERATIONS WERE CONDUGTED ON A FIVE-DAY PER WEEK BASIS; HOWEVER, SOME WEEKEND WORK WAS NECESSARY TO REWORK WASTE gOLUTIONS CONTAININO TETRAVALENT PLUTONIUM POLYMER WHICH FORMED IN THE PEED STREAM.

TWO BRIEF UNSCHEDULED OUTAGES WERE NECESSARY OURING THE MONTK POR PROCESS ADJUSTMENTS TO LOWER PLUTONIUM WASTE LOSSES.

SOME DIFPICULTY WAS EXPERIENCED WITH THE GAMMA ACTIVITY OP BOTH PRODUCT STREAMS. THE PLUTONIUM PRODUET WAS MAINTAINED WITHIN SPEGIPICATIONS BY CONTINUED OZONATION. A PORTION OF THE URANIUM OUTPUT REQUIRED BLENDING.

WASTE LOSgES AVERAGED $0.52 \%$ OF THE PLUTONIUM PHROUGHPUT AND $0.12 \%$ OF THE URANIUM THROUGHPUT. KIGH WASTE LOSSES WHICH WERE EXPERIENCED AT THE BEGINNING OF THE MONTH RESULTED YROM THE TETRAVELENT PLUTONIUM POLYMER WHICH KAD PORMED IN THE DISGOLVER GOLUTION.

IODINE EMISSIONS AVERAGED O.41 GURIES PER OAY.

UO - Pl.ANT PRODUCTION OF NORMAL UO 3 TOTALED 553 TONB, $190.6 \%$ OF FORECAST. ENAICHED UOZ PRODUCTION TOTALED 48.2 TONg, $102.6 \%$ OP PORECASY. ALL SHIPPING SCHEDULES WERE MET.

FOR EACH TON OF URANIUM PROCESSED, 938 POUNDS OF NITRIC ACID WAS RECOVERED AT AN AVERAGE CONCENTAATION OF 15\%. THE LOW RECOVERY 19 BELIEVED DUE TO AN INVENTORY ERROR IN NOVEMBER MHICH RESULTED IN AN EXCESSIVE RECOVERY FIGURE FOR YHAT MONTH.

TWO SUCCESSPUL AUTORATED SHUTDOHNS WERE MADE ON K CALCINER DURINC THE MONTH. 


\section{RESEARCH AND DEVELOPMENT}

NeptuniUm Processing - Approximately 1,090 grams of neptunium was separated at puhex during the RUN BEGUN IN NOVEMEER ANO COMPLETED DECEMBER 3. DURING THE FIRST WEEK OF DECEMBER THE FIRJT NEPTUNIUM SEPARATION RUN AT REDOX WAS MADE. APPROXIMATELY 70 GRAMS OF NEPTUNIUM WAS SEPARATED DURING THIS RUN. IN ADDITION TO THE ABOVE, 420 GRAMS OF NEPTUNIUM AS NITRATE WAS RECEIVED FROM Paducah and 335 grams was received from savannah River as oxide.

EIght fabricated palm elements Were shipped to SaVANNah RIVER on December 14 as part of CAMPAIGN VIII. A 'IINTH ELEMENT COLLIDED WITH THE GUIDE ELOCK DURING EXTRUSION AND WAS SEYERELY GOUGED, REQUIRING TEPROCESSING, DURING THE LAST WEEK OF DECEMBER THE HYDRAULIC SYSTEM FOR THE EXTRUSION PRESS FAILED. AT MONTH END, REPAIRS WERE IN PROCESS AND WERE EXPECTED TO BE COMPLETEO SHORTLY.

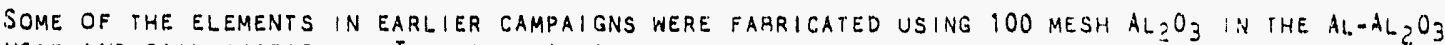
NOSE AND TAIL SECTIONS. THIS GANE A ROUGH APPEARING EXPOSED END, WHICH CAUSED SOME CONCERN TO SAVANNAH RIVER FROM A POROSITY STANDPOINT. THE FIRST EIGHT ELEMENIS OF CAMPAIGN IIII hERE FABRICATED FROM THE SAME 100-MESH AL $2 \mathrm{O}_{3}$; BUT GOTH ENDS OF THE ELEMENTS WERE COVERED SY NEL.DING ALUMINUM DISCS TO THE ENDS. ALL OTHER ELEMENTS OF THIS CAMPAIGN ARE BEING MADE WITH - 325 MESH Al $\mathrm{O}_{3}$. THESE ELEMENTS ARE SATISFACTORY.

DURING THE FIRST NEPTUNIUM SEPARATION RUN AT REDOX, 70 GRAMS WERE RECOVERED FOR FURTHER PRO. CESSING. THIS WAS 37\% OF THE TOTAL NEPTUNIUM ESTIMATED TO HAVE BEEN IN THE COLUMNS AT THAT time. These results are encouraging. The proceuUre consisted of the rollowing steps:

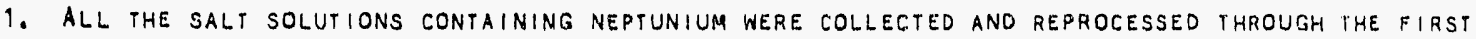
EXTRACTION CYCLE USING A SPECIAL FLOWSHEET TO REDUCE THE VOLUME ANO FISSION PRODUCT CONTAMINATION.

2. THE SOLUTION WAS MADE ACID DEFICIENT AND PROCESSED iHROUGH THE SECOND CYCLE WHERE URANIUM AND PLUTONIUM WERE EXTRACTED GY THE SOLVENT. THE NEPTUNIUM REMAINED IN THE AQUEOUS SOLUTION WHICH WAS SENT TO THE SECOND STAGE FEED TANK.

3. THE AqUEOUS SOLUTION WAS THEN REPROCESSED iHROUGH THE SECOND CYCLE ON AN ACID FLOWSHEET AND THE NEPTUNIUM WAS EXTRACTED GY THE SQLVENT, SEPARATING IT FROM THE BULK OF THE FISSION PROOUCTS.

4. NEXT, THE NEPTUNIUM SOLUTION WAS SENT TO THE 1B (PARTITIONING COLUMN) WHERE THE NEPTUNIUM WAS STRIPPED INTO THE ACID DEFICIENT AQUEOUS SALT SOLUTION.

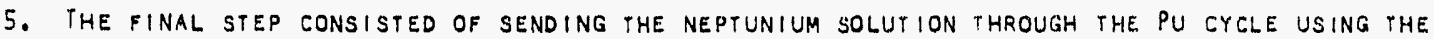
NORMAL PLUTONIUM FLOWSHEET.

THE OVER-ALL ARITHMETICAL FISSION PRODUCT DECONTAMINATION FACTOR WAS $1 \times 10^{7}$ RESULTING IN $1 \times 10^{4}$ MICROCURIES GROSS GAMMA PER GRAM NEPTUNIUM IN THE PRODUCT.

GETR GRAPHITE IRRADIATIONS - THE H-2 EXPERIMENT IN THE E-7 POSITION OF THE GETR WAS DISCHARGED DECEMBER 5 AFTER A CALCULATED EXPOSURE OF $1.2 \times 10^{21}$ NVT. THE EXPERIMENTAL ASSEMBLY WAS FOUND TO BE BADLY DETERIORATED WITH SOME GRAPHITE SHATTERED. HOWEVER, MANY OF THE SAMPLES APPEAR TO BE IN SATISFACTORY CONLITION FOR MEASUREMENT. THE MECHANISM RESPONSIBLE FOR OETERIORATION OF THE CAPSULE IS THOUGHT TO BE OVERHEATING, WHICH IN TURN RESILLTED FROM UNDERESTIMATING THE GAMMA HEATING EFFECT. LABORATORY STUDIES OF POSSIBLE MECHANISMS, INVOLVING SUCH FACTORS AS CHEMICAL OR METALLURGICAL REACTIONS ANO THERMAL SHOCK ARE UNDER WAY WHICH WILL AID IN A MORE COMPIETE DETERMINATION OF THE CAUSES. THE GRAPHITE LUMPS IN THE CAPSULE ARE BEING ANALYZED I. TERMINE IF A METAL-GRAPHITE REACTION OCCURRED.

FISSION PRODUCT RECOVERY - A FISSION PRODUCT RECOVERY TEST RUN WAS COMPLETED AT PUREX DURING THE NEPTUNIUM PROCESSING PERIUD EARLY IN DECEMBER. THIS WAS THE MOST PROMISING RUN TO OATE. GREATER THAN $90 \%$ OF THE CERIUM WAS REMOVED DURING THE SULFATE PRECIPITATION STEP. THE IRDN CONTENT OF THE SULFATE PRODUGT INDICATED AN IRON SEPARATION FACTOR OF GREATER THAN 60. HOWE.VER, THE SECOND PRECIPITATION TEST (PEROXY ACETATE) WAS INVALIDATED BY AN OPERATING ERROR WHICH PRDDIJCED A PH OF 1.6 INSTEAD OF THE PRESCRIBED 4 TO 5 . THE RUN TO THAT POINT HAD INDICATED MUCH MORE SUCGESSFUL CONTROL OF PH THAN HERETOFORE OBTAINED. 


\section{DOCUMENT NO. HAN-74331}

PLANT ACQUISIIIION AND CONSTRULTION

\section{PROJECT ANO DESIGN STUDIES}

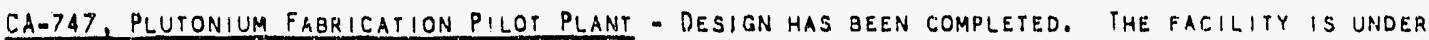
PARTIAL OCCUPANCY BY THE USER WITH.THE PEMAINING INSTALLATION OF EQUIPMENT BE:NG HANDLED BY A CPFF CONTRACTOR.

CG|.791 Reactor CONf Inement - The General Electric COMpany has completed and iransmitted to AEC WHOO A STUDY ON SEALING EXISTING BUILDINGS. THE STUDY INDICATES THAT MAINTAINING A SL:GHT NEGAT!VE BUILDING PRESSURE IS THE MOST PRACTICAL METHOD OF CONTROLLING RELEASE RESULTING FROM INCIDENTS. AS SOON AS SUPPORTING DOCUMENTS ARE RECEIVED THE STUUY WILL BE TRANSMITTED TO THE WASHINGTON OFFICE.

The A. O. Littige Company has started testing act IVAted charcoal as f:-ier med a for halogen

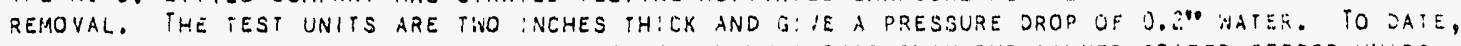
RESIOTTS IND:CATE THAT THIS MEZ:UM IS SIGNIFICANTLY BETTEG THAN THE SILYER-COATEE ZOPPER UNITS PREVIOUSLY TESTED.

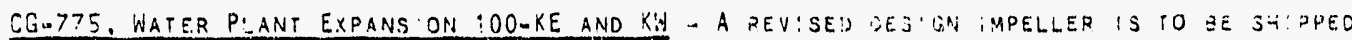
ABOUT M! J-JANUARY TO REPLACE THE IMPELLER THAT SHOWED EXCESS!VE CAYITATION IN THE PROIOTYPE HIGH-_IFT PUMP.

A NEN PROPOSAL (CGI-B83) IS BE:NG PREPARED REQUESTING FUNDS FOR MOD:FY ING A PROCESS PUMP : N 100-KW AND FOR PROVIDING TOTAL DESIGN OF THE PROJECT.

CG1-802, PROCESS SAFETY MONITORING SYSTEM - HIGH-SPEED SCANNING TYPE fOR TEMPERATURE MON: TORING - FIRST PHASE DESIGN ANO FABRICATION OF A 116-POINT SYSTEM HAS BEEN AWARDED TO EPSCO, INC., THROUGH THEIR SUBSIDIARY MON!TOR.SYSTEMS, INC. SYSTEM DESIGN IS COMPLETE, AND NORK IS PROCEEDING ON VARIOUS SUBASSEMBLIES TO PREPARE THEM FOR TESTING.

CAH-82? PRESSUR IZES GAS-COOLED LOOP FAC!LITY THIS FACILITY IS TO BE INSTALIED :N THE PLU. TONIUM RECYCLE TEST REACTOR. DESIGM AND FABRICATION OF THE OUT-OF-PILE (PHASE I) PORTION IS BEING CONT INUED GY THE STRUTHERS-WELLS CORPORATION. THE GENERAL ELECTRIC COMPANY IS $44 \%$ COMPLETE WITH DESIGN ON THE IN-PILE PORTION (PHASE 11 ).

CGC-830, PLANT MOD IFICATION FOR REPROCESSING NONPRODUCTION, ReACTOR fUELS - FOLLOWING the WASHINGTON! HEADQUARTERS REQUEST, DESIGN HAS BEEN STOPPED PENDING A STUDY BY PRIVATE INOUSTRY ON THE POSSIBILITY OF COMMERLIALLY PROCESSING THESE FUELS. THE PROJECT IS BEING RE-EVALUATED ON THIS BASIS.

CAH-870, FACILITIES FOR RECOVERY OF RADIOACTIVE CERIUMA - 325 8UILOING - THE ARCHITECT - ENGiNEER HAS COMPLETED PRELIM!NARY DES:GN AND IS $51 \%$ COMPLETE, ON SCHEDULE, FOR DETAILED DESIGN.

CGC-872. PALMOLIVE FABRICATION AND REPROCESSING FACILITIES - 200 EAST AREA - ADVICE has beEN RECEIVED THAT NO FURTHER ACTION IS REQUIRED ON THIS PROJECT, AS A COMPLETION ITEM, A STUUY IS GEING MADE TO DETERMINE THE BEST FORM FOR SHIPPING PALM.

AEC-167, PLUTONIUM ReCYCLE TEST REACTOR - A REVISED CONSTRUCTION SCHEDULE IS BEING PREPARED to INCLUDE SCOPE CHANGES THAT HAVE OCCURRED DURING PROGRESS OF THE PROUECT. THE SCHEDULE W:LL. SHOW THE SAME COMPLETION DATE AS THE PREVIOUS SCHEDULE.

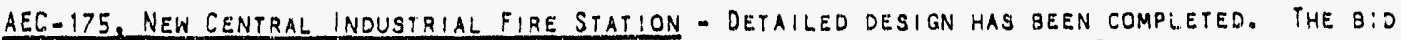
PACKAGE IS TO BE ISSUED EARLY IN JANUARY FOR A BID OPENING ON JANUARY 26. 


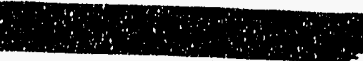

DOCUMENY NO. HAN-74331

PLANT CONSTRUCTION

Major CONSTRUCtion - THE status of major consiruction is indicated gelow:

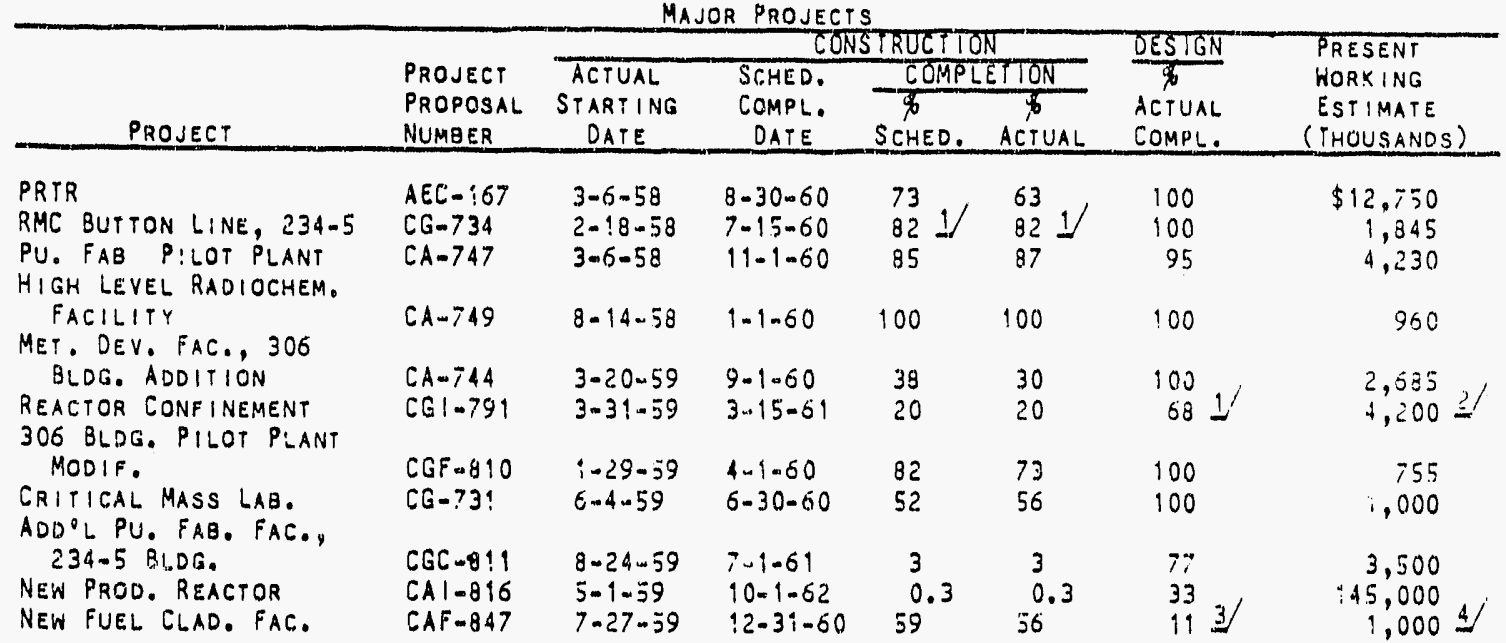

$1 /$ BASED ON REVISED SCOPE OF WORK.

2/ PORTION OF $\$ 6,000,000$ CONFINEMENT PROGRAM.

3 DESIGN IS BASED ON $\$ 3,600,000$ PROJEET.

4 PORTION OF $\$ 3,600,000$ PROJEGT.

CG1-791, REACTOR CONFINEMENT PROGRAM, CONTRACT AT(45.1) 1.687 -

Phase I, fog spray systeas, J. A, joneg congtruction Company. acceptance tests have been RUN ON THE FOO SPRAY SYSTEMS IN ALL AREAS, AND ONLY MINOR EXCEPTIONS AEMAIN TO GE COMPLETED.

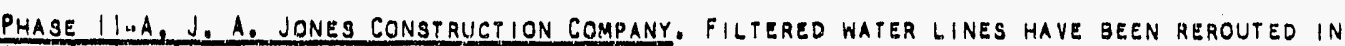
100-F, 100-0R, 100-0, AND 100-8 AREAS.

IN 100-KE AREA THE 105 BUILDING UNDERGROUND POWER GABLES FROM 105-KE AND 115-KE 8UILDINGS HAVE BEEN COMPLETED.

IN 900-KW THE CONGRETE PLOOR, GENTER WALL, OUTSIOE WALLS, AND ROOF SLAB FOR THE AIR DUCTS have beEN PLAGED. REROUTING OF the UNDERGROUNo POWER CABLES From 105-KW AND 115-KW have BEEN COMPLETED.

Phase 11-8, Contract aT(45-1)-1483, Filter BuIlding, R. B. Miles Construction company. EXCAVATION WAS COMPLETED ANO THE IRST FOUNDATION CONCRETE PLACED IN 100-F AREA. THE EXCAVATION POR THE PILTER GUILDING IN THE 100 H AREA WAS gTARTED ON DECEMBER 14, AND IN THE 100-C AREA ON DECEMBER $28,1959$.

CONTRACT AT(45-1)-1446, PROJECT CG-731, CRITICAL MASS LABORATORY, H, S. WRIGHT CONBTRUCTION CO. THE PIPE FITTERS, WMO WALKED ORF THE JOB ON DECEMBER 9,1959 , IN A DISPUTE WITH THE SHEETMETAL WORKERS, HAVE NOT RETURNED TO WORK. THERE HAVE geEN NO SIGNIFICANT DELAYS TO DATE; HOWEVER,

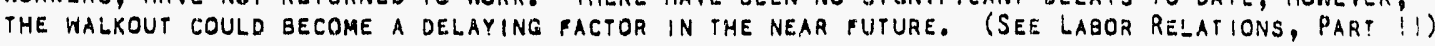

CONTRACT AT(45-1)-1477, PROJECT AEC-167, PRTR, CUSTODIS CONSTRUCTION COMPANY.

Phase 11 - The concrete chimmey reached its maximum height of 161 reet on decemeer 22, 1959. CONTRACT AT (45-1)-1410, PROJECT AEC-167, PRTR, SHAW \& E3TES.

PHAgE III - INSTALLATION OF the PRIMARY COOLANT RECIRCULATION PIPING WAS STARTED DURING the WEEK ENDING DECEMBER 30, 1959.

THE WELDS ON THE INNER BIOLOGICAL SHIELD ARE BEING CHECXED ON A TWO-SHIPT BASIS BY THE HELIUM SNIFTER METHOD.

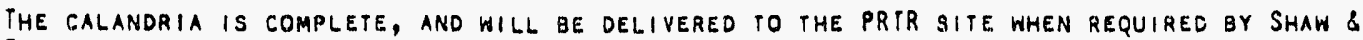
ESTES.

NINETY-FIVE ZIRCONIUM TUBES FOR PRTR HAVE GEEN RECEIVEd FROM THE TUBE REDUC:NG CORPORATION.

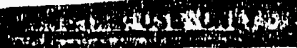

PAGE * 10

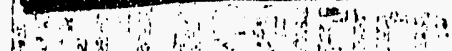




\section{DEPIASSHED}

DOCUMFNT NO. HAN-74339

PLANT CONSTRUCTION (CONT DD)

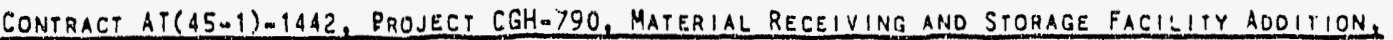
BUILDING NO. 327,300 AREA. JENSEN-RASMUSSEN \& COMPANY. THE SIDING AND ROOF DECXING FOR THE 327 BUILOING AODITION ARRIVED ON DECEMBER 18, 1959.

CONTRACT AT(45-1)-687. PrOJECT CGF-810, 306 BUI:LING PILOT PLANT MODIFICATION, J. A. JUNES. THE LAST GARLOAD OF PARTS FOR THE 2750 -TON PRESS, PURCHASED FROM THE LOWEY HYOROPRESS GORPORATION, ARAIVED DECEMBER $18,1959$.

CONTRACT AT(45-1)-1479, PROJECT CGG 850 , PUREX WASTE CRIB NO. 216-A, anO RELATED WORK, 200. EAST FRANK H. LOHSE. BENEFICIAL USE OF CRIB NO. 216-A WAS OBTAINED DECEMBER 12, 1959.

CONTRACT AT(45-1).1455, PROJECT CA 1.816, NEW PROOUCTION REACTOR, KAISER ENGINEERS.

SURCONTRACTS:

SC..2. Head Mechanical, inc., completed work on the luc inater line deceinger 2:, 1959.

SC.4. THE 13.8 KV TRANSMISSION LINE AND DIJTRIGUTION LINES FOR TEMPORARY POWER COR iHE NPR AREA WAS ENERGIIËD gY TULi-AR POWEa CONSTRUCTION COMPANY ON DECEMBER i, 1959.

SC-8 - PROJECT CAE-E52 - THE SITE WORK ON SUPPORTING TELEPHONE FACILITIES FOR NPR HAS BEGUN DECEMBER 7, 1959, BY TULLAR POWER CONSTRUCTION COMPANY.

SC-10. WORK ON THE RIVER WATER PUMP hOUgE WAg STARTED DECEMBER 16, 1959, GY JeNSENRASMUSgEN \& COMPANY AND B-E-G-K CORPORATION.

SE-:1 - George a Grant giarted work on the tuc guildoings and cacilitiles december 14, 1959.

BIDS HAVE BEEN EITHER INVITED OR RECEIVEO POR LUMP-gUM CONSTRUCTION ON 1 T34 STORAGE

FACILITIES, MODIFICATIONS TO THE WHITE GLUFPS TUBE SHOP, AND ARCHITEGTURAL MOD!PICATIONS

TO THE 2101 BUILDING.

The Irgt zIrconium tube pabricated under the contragt with the harvey aluminum company was DELIVERED TO HANPORD ON DECEMBER 16, 1959.

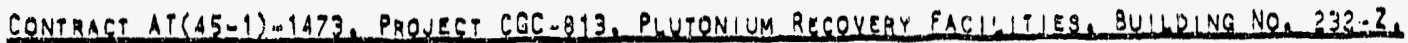
COOH GEORG A GRAMT INC ASBESTOS CEMENT PIPE PITTINAS, WHICH HAD BEEN DEISAYING PROGRESS ON THIS CONTRACT, WERE RECGI VED DECEMBER 29, 1959,

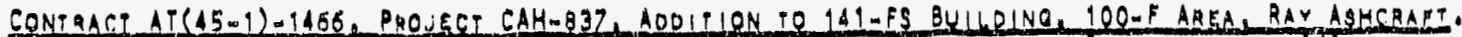
BENEPICIAL USE OF THE BUILDING BY TME USINO OEPARTMENT WAS ASSUMED ON DECEMBER 18, 1959.

\section{PROCUREMENI}

THE ATOMIC ENERgY COMMISSION APPROVED 36 aWARDS MAOE aY GENERAL ELECTRIC COMPANY IN THE TOTAL AMOUNT OP $\$ 3,102,511,22$. ANO PIVE AWARDS MADE BY KAISEA IN THE TOTAL AMOUNT OP $\$ 5.231,506$.

THE ATOMIE ENERGY COMMISgION PLACED 266 PURCHAQE ORDERS YOR THE TOYAL AMOUNT OY \$320,784.14. AMONG THE LARQER OADERS WERE:

1. General electale company placed an order with the commercial steel fabricatorg fur the

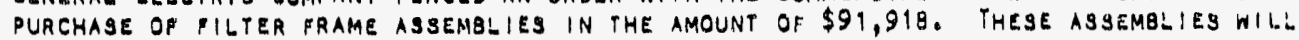
BE UIED ON PROJECT CGI-791.

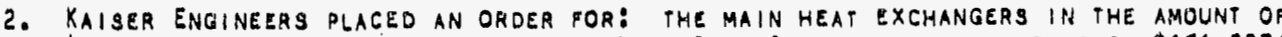
$\$ 4,600,000$; A WATER SCREEN WITH THE LINK BELT COMPANY IN THE AMOUNT OF \$151,287 AND gIX CIRCULATING WATER PUMPS (4 ELECTAIC AND TWO DIESEL DRIVEN) FROM BYRON JACKSON PUMPS, INC., IN THE AMOUNT OP $\$ 403,900$.

\section{PROPERTY}

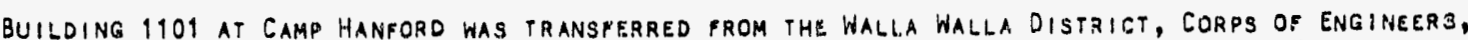
TO THE ATOMIC ENERgy COMMISSION ON DECEMaER 10, 1959. THE GUILDING WILL aE USED OY KaISER ENGINEERS AS A JOB SITE OPFICE BUILDING. 

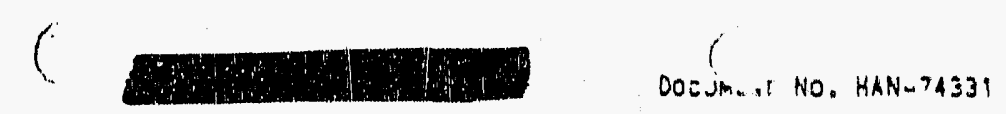

\section{CONTRACTS}

THREE CONTRACTS WERE AWARDED DUR!NG THE HONTH OF OECEMGER GY AEC:

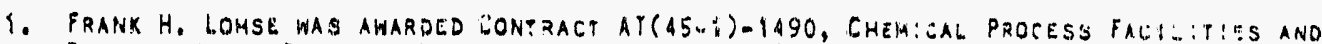
REl.ATED WORK, BUI:. JING NO. 306, 300 AREA, HOR $\$ 449,950$.

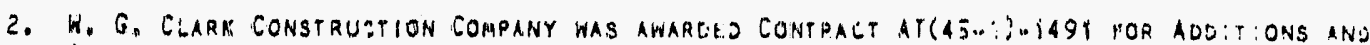

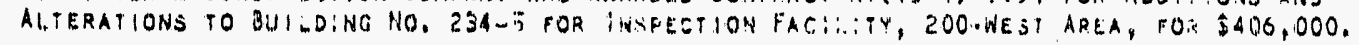

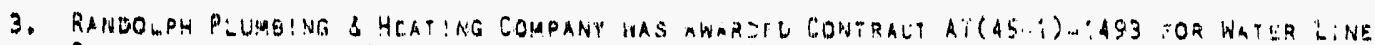
REPLACEMENT, WHITE B:UF": IN THE AMOUNH OP \$59,439.

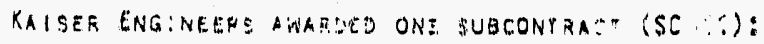

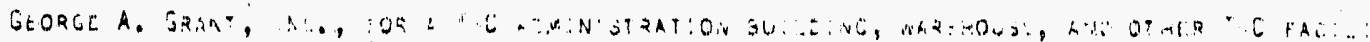

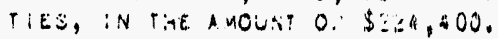

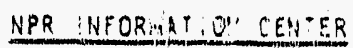

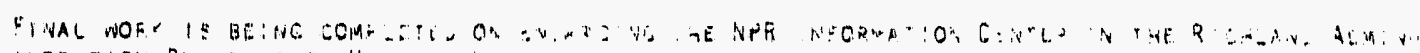

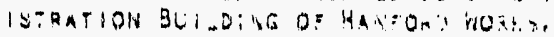


AIR MAIL

Deteroviruats

TO: Director, Division of Production

SAit 111300 USAEC, Washington, D. C.

FROM: J. E. Travis, Manager, Eanford Operations

Office, USAEC, Richland, Washington

SUBJECT: MONTELY STATUS AND PROGRESS REPORT

SYBOL: B:RHL

Enclosed herewith is Part II ("Official Use Only" portion) of subject report for the month of.

The "Secret" portion, Part I, is forwarded as a seperate report.

Enclosure:

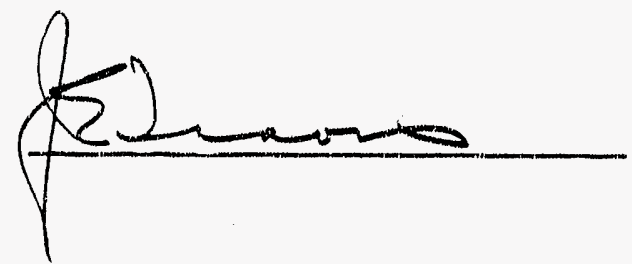

Montlily Status and Erogress Report, Part II

\section{DISEIIULIOT:}

IC Cowies - acinessee

- Copy - Donstuction Inotneerina a Suply Jivision

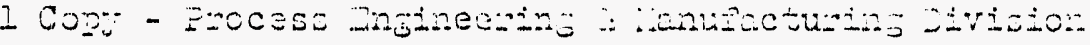

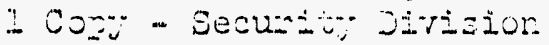

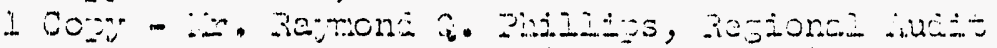

- Con - Classized Fies (Acaciaj ziza)

$\rightarrow 100 \%$ - 3ucjot vivisio: 
U. S. ATOMIC ENERGY COMMISSION HANFORD OPERATIONS OFFICE

MONTHLV STATUS AND PROGRESS REPORT

DECEMEER 1959

PART 11 
MONTHLY STATUS AND PROGRESS REPORI

HANFORO OPERATIONS OFFICE

DECEMBER 1959

PARY II

C $\underline{N} \underline{N} \underline{E} I \underline{S}$

PAGE NO.

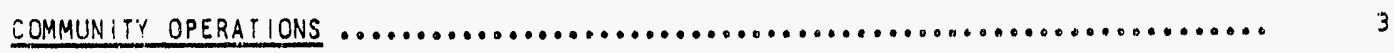

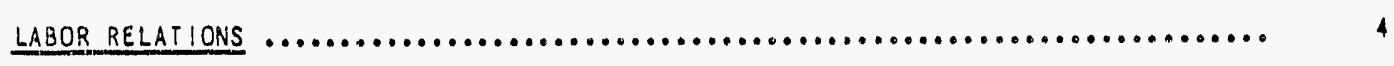

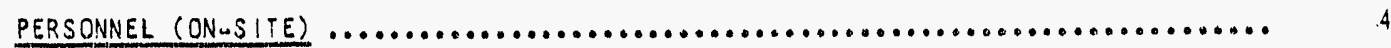


GOYERNMENT HOUSING:

THE FOLLOWING ARE HOUS:NG STATISTICS FOR DECEMBER 1959:

DECEMBER 1 DECEMBER 3 !

A. Total houses aval:able fop occupancy

i. TOTA- HOUSES OGCUPIED

2. TOTAL HOUSES UNOCCLPIEO

(A TOTAL OF $3,78 E$ SINGLE HOUSES AND 1,007

DUP.EKES SOLO - 5, ४0O UNITS.)

8. COTA. APARTMENTS AVAIIABLE FOF OCCUPANCY

$\therefore$ OOTA... ADARTMENTS OCCUP!ED

$\therefore$ TOTAL aLARTMENT S UNOCrUP!Ez

.36

133

34

33

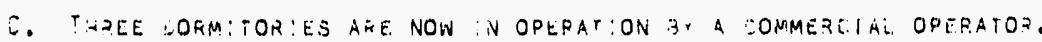

PZ : ANE HOU: INS UN:TS (WHERRY ACT):

\begin{tabular}{|c|c|c|c|c|c|}
\hline & \multicolumn{2}{|c|}{ COLUMB: A HEIGRTS } & \multicolumn{2}{|c|}{ SPOKANE HOUS:NG } & \multirow[b]{2}{*}{ TOTAL UNA:TS } \\
\hline & HOUSE'S & ADTS. & HOUSES & APTS. & \\
\hline TOTA: INTET & 280 & 220 & 400 & 100 & $\because, 000$ \\
\hline $\begin{array}{l}\text { REEVTED } \\
\text { VACANT }\end{array}$ & $\begin{array}{l}149 \\
131\end{array}$ & $\begin{array}{l}120 \\
100\end{array}$ & $\begin{array}{c}396 \\
4 \mathrm{~V}\end{array}$ & $\begin{array}{l}97 \\
13\end{array}$ & $\begin{array}{l}752 \\
\therefore 48\end{array}$ \\
\hline
\end{tabular}

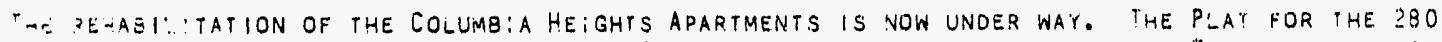
HOLJEJ WAS APJROYED GY THE C:TY PLANNING COMMISSION AND WAS SUBM:TTED TO THE COUNTY FOR QECORD.

1.VG. THE COUNTY HAS REFUSED TO ACCEPT THE PIAT YOR RECORDING BECAUSE OF A STATUTORY REQUU!REMENT THA AL: 3ACK TAXES MUST BE PAID. THE FHA COINTENOS THAT THE HOUSING HAS BEEN LISTED AS PERSONALTY ANT THE NATiONAL HOUSING ACT DOES NOT PERMIT PAYMENTS IN LIEU OF TAXES ON PERSONALiY.

D:SPOSA::

ON DESEMBER 11, 1959, THE HHFA ADVERTISED FOR SALE 106 VACANT RESIDENTIAL, COMMERCIAL ANO :NOUSTR:AL PROPERT:ES.

ON DECEMBER :8, 1959, HHFA ADVERTISED 11 UPTOWN COMMERC:AL PROPERTIES AND ONE LiGHT :NDUSTR:AL PROFERTY FOR SALE.

A :-:ST OF TEN COMMERCIAL AND TWO NONCOMMERCIAL PRIDR:TY APP:-ICANTS WAS POSTED ON DECEMBER Z4. THE APPEAL. PERIOD CLOSES JanUARY 4, 1960.

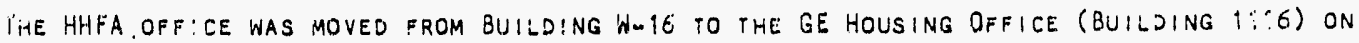
DẼ EMgEP $2 \hat{\imath}$.

i'TE REPORT OF SALES FOR THE MONTH, ENDING DECEMBER 31, 1959, is AS FOLLOWS:

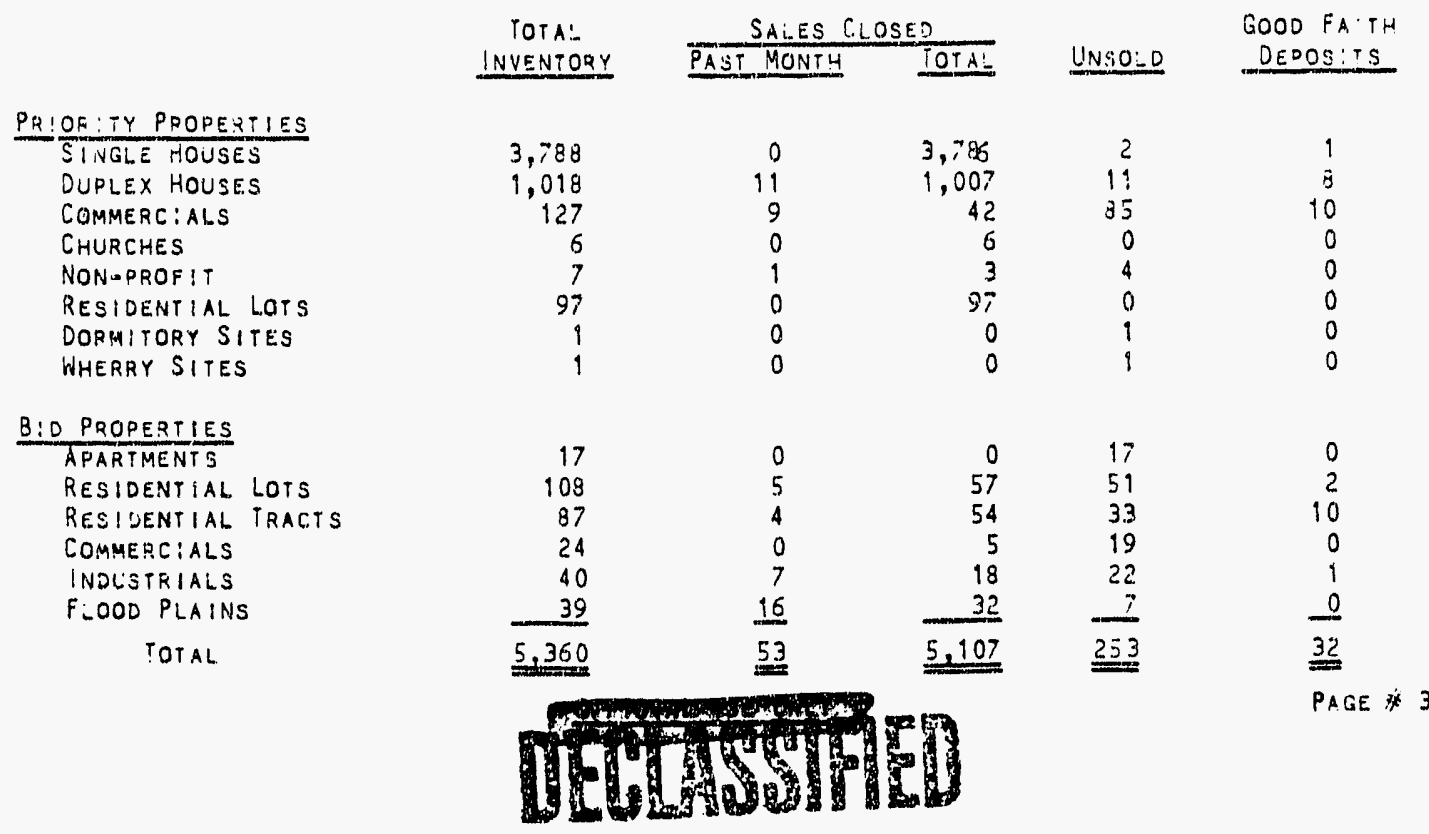




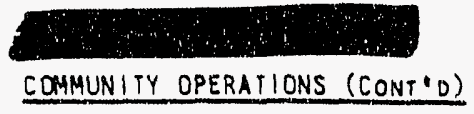

HOSP:TAL

KADLEL METHODIST HOSPITAL SUBMITTED THEIR REQUEST FOR PUNDS PDR CALENDAR yeaR 1960 IN the AMOUNT OF $\$ 53,720.95$. THIS AMOUNT COMPARES FAVORABLY WITH THE BUDGETED ESTIMATE OF $\$ 52,000$. AFTER THIS PAYMENT IS MADE THERE REMAINS A CONTRACT BALANCE OF $\$ 66,774,64$ AVAILABLE For CALENDAR YEAR 1961 ASSISTANCE PAYMENTS.

MUNICIPAL

A CHECK IN THE AMOUNT OF \$80,000 WAS SENT AS AN ASSISIANCE PAYMENT TO IHE CITY OF R!CHLAND FOR THE MONTH OF DECEMBER.

REAL ESTATE

THE. YAK:MA OFF:CE OF THE DEPARTMENT OF JUSTICE WROTE ITS MASH:NGTON CHFF: CE RECOMMENDING AN APPEAL OF JUDGE LiNDBERG ${ }^{\circ} S$ ACCEPTANCE OF THE COMM!SSIONERS' AWARDS ON THE WAHLLKE S:OPE. THERE ST:LL ARE PENSING 161 IRACTS, WITH 28,193 ACRES, TO BE SETTLED ON WAHLUKE SLOPE.

\section{LAEOR RELATIONS}

BECAUSE OF A jURiSOICTiONAL DiSPUTE W:TH THE SHEETMETAL WORKERS, FDUR PIPEF:YTERS EMPLOYED BY UN:VERS:TY P:UMMING AND HEATING, MECH.AN:CAL. SUBCONTRACTOR TO HOWARO S. WR!GHT CO., F:XECUPRICE CONTRACTOR ON THE CRITICAL MASS LAEORATORY FAC:LIIIES PROJELT HAVE REFUSEO TO REPORT FOR NORK SINCE DECEMBER 9, 1959. THE DISPUTE INVOLIES THE INSTALLATION OF SCHEDULED PIP:NG FOR VENT:NG PURPOSES.

THE INTERNATIONAL OFFICES OF THE PLUMBERS UNION AND THE NATIONAL JOINT BOARD FOR SETTELEMENT OF JLR; SEICTIONAL DISPUTES HAVE ISSUED DIRECTIVES TO THE WORKERS TO RESUME WORK. TO DATE, HOWEVER, THE. MEN HAVE ELECTED NOT TO HONOR THESE REQUESTS.

\section{PERSONNEL (DN $-S \mid T E)$}

DECEMBER 1

ATOMIC ENERGY COMMISSION GENERAL ELECTRIC COMPANY TOTAL CONSTRUCTION PERSONNEL

total Project Personnel.

\begin{tabular}{rr}
279 & 279 \\
7,839 & 7,803 \\
852 & 849 \\
\hline 8.970 & 8.931 \\
\hline
\end{tabular}

\section{DECEMBER 31}


$\nabla$
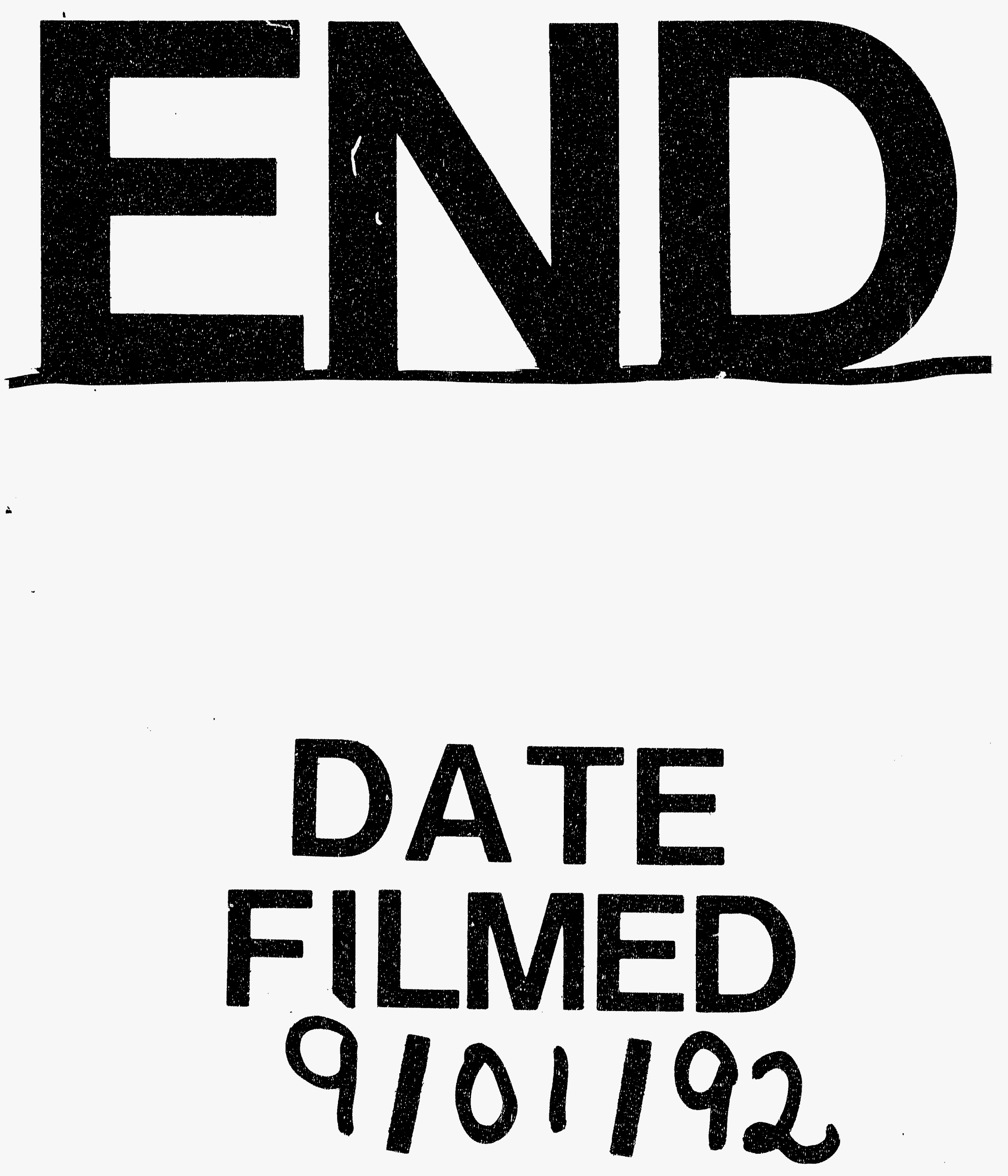
$=$ 